\title{
Awake Craniotomy: Pengalaman dengan Dexmedetomidin
}

\author{
Dewi Yulianti Bisri, Tatang Bisri \\ Departemen Anestesiologi dan Terapi Intensif Fakultas Kedokteran Universitas Padjadjaran-RSUP Dr. Hasan \\ Sadikin-Bandung
}

\begin{abstract}
Abstrak
Awake craniotomy (AC) menggunakan anestesi lokal dan sedasi termonitor untuk mengambil tumor intrakranial yang mengenai eloquent cortex merupakan teknik yang telah diterima. Teknik ini memungkinkan dilakukan pemetaan intraoperatif yang memfasilitasi reseksi tumor secara radikal dan meminimalkan morbiditas dengan mempertahankan jaringan yang berfungsi. Kebutuhan pemetaan cortex adalah untuk menggambarkan fungsi otak, seperti bicara, sensoris, dan motoris dengan tujuan untuk mempertahankannya selama dilakukan reseksi. Obat yang diberikan harus dapat memberikan level sedasi dan analgesi yang adekuat untuk mengangkat tulang, tapi tidak mempengaruhi testing fungsonal dan elektrokortikografi. Prosedur sama dengan kraniotomi standar, tapi dengan satu perbedaan-pasien sadar penuh selama pemetaan korteks dan reseksi tumor. Pasien mampu bicara dan bergerak normal. Pasien tidak selalu bangun selama pembedahan, tapi tidur dalam 1-2 jam pertama dan atau setelah reseksi tumor. Tidak ada rasa sakit selama sadar. Sasaran anestesi adalah pasien nyaman, mampu tidak bergerak selama pembedahan, sadar dan kooperatif saat pemetaan korteks yang dapat dicapai dengan: 1) persiapan pasien yang adekuat, 2) lingkungan nyaman, 3) pemberian sedatif analgesik yang tepat, 4) selalu berkomunikasi dengan pasien, dan 5) cepat diterapi bila ada komplikasi. Dexmedetomidine adalah suatu a-2 adrenoceptor agonist spesifik dengan efek sedatif, analgesik, anesthetic sparring effect, bangun bila distimulasi, efek proteksi otak, tidak adiksi, tidak menekan respirasi. Pasien yang diberikan dexmedetomidin bisa tersedasi dan nyaman tapi mudah dibangunkan dan mentoleransi AC yang berlangsung lama.
\end{abstract}

Key words: awake craniotomy, analgesik sedatif, dexmedetomidin

JNI 2015;4(3): 212-22

\begin{abstract}
Awake craniotomy (AC) using local anesthesia and monitored sedation in intracranial tumor removal involving eloquent cortex has been considered as an acceptable technique. It allows intraoperative mapping that facilitates radical tumor resection while minimizing morbidity by preserving functional tissue. Anesthesia for intracranial procedure requiring patient cooperation present a challange to the anesthesiologist. The need for cortex mapping is to describe brain function, such as verbal, sensoric and motoric aiming for maintain its function during resection. The administered drugs should provide an adequate level of sedation and analgesia for bone flap removal, but must not interfere with functional testing and electrocorticography. The procedure is very similar to a standard craniotomy, but with one difference-the patient is fully awake during cortical mapping and tumor resection. Patient is able to talk and move normally. The patient should not awake during surgery, but is in deep sleep for the first 1-2 hours and/or after tumor resection. There will be be no pain during conscious time. The goal of anesthesia is patient's comfort, able to stay immobile on OR table during the procedure, and is alert and cooperative to comply with cortical mapping. These goals can be accomplished by 1) adequate preparation of the patients, 2) a comfortable environment, 3) appropriate administration of right analgetic and sedative medication, 4) conduct ongoing communication, 5) perform rapid treatment to any complications. Dexmedetomidine is a highly spesific a-2 adrenoceptor agonist with sedative, analgesic, anesthetic sparring effect, awake if stimulated, brain protection with no addiction effect nor suppress ventilation. Patients treated with dexmedetomidine will be sedated, comfortably but is easily aroused to tolerate a prolonged awake craniotomy.
\end{abstract}

Awake Craniotomy: Experience with Dexmedetomidine

Key words: awake craniotomy, analgesic sedative, dexmedetomidine

JNI 2015;4(3): 212-22 


\section{Pendahuluan}

Anestesi untuk prosedur intrakranial yang memerlukan pasiennya tetap sadar dan kooperatif merupakan tantangan bagi spesialis anestesi. Obat yang diberikan selama tindakan harus mampu memberikan level analgesi dan sedasi yang adekuat saat memotong tulang tengkorak, akan tetapi, harus tidak mempengaruhi test untuk fungsi otak dan elektrokortikografi. ${ }^{1,2}$ Anestesi untuk awake craniotomy (AC) bervariasi dari anestesi lokal ke anestesi umum dengan pasien harus bangun intraoperatif selama dilakukan mapping language dan reseksi tumor. ${ }^{3}$ Awake craniotomy dengan menggunakan obat anestesi lokal dan sedasi termonitor untuk operasi tumor intrakranial yang mengenai eloquent cortex merupakan suatu teknik yang dapat diterima. Dengan teknik ini dapat dilakukan pemetaan intraoperatif yang menyebabkan dapat dilakukan reseksi tumor yang lebih radikal serta meminimalkan morbiditas dengan memelihara jaringan otak yang mempunyai fungsi. ${ }^{1,2}$ Awalnya, teknik AC digunakan untuk mengeluarkan fokal epileptik dan reseksi tumor yang mengenai korteks serebri yang mempunyai fungsi (eloquent cortex). Hal ini berdasarkan premis bahwa keuntungan $\mathrm{AC}$ adalah adanya kesempatan dokter bedah untuk melakukan pemetaan otak sehingga rute operasi akan lebih aman dan mampu mengurangi morbiditas. Selain itu, juga mempunyai keuntungan lain yaitu menghindari anestesi umum dan pemasangan monitor invasif sehingga mungkin akan menurunkan morbiditas pascabedah dan memperpendek lama tinggal di rumahsakit. ${ }^{2,4}$

Baru-baru ini, AC digunakan untuk mengeluarkan semua tumor supratentorial, bukan saja yang mengenai eloquent cortex. Teknik ini komplikasinya sedikit dan menurunkan lama tinggal di ICU dan RS tanpa mengurangi kualitas perawatan pasien. ${ }^{3}$ Sebagai contoh, dengan memperbaiki teknik anestesi dan teknik pembedahan, di The Toronto Western Hospital, Toronto, Canada, AC diperlakukan sebagai bedah rawat jalan dan pasien dipulangkan 6 jam pascabedah atau nginap 1 malam. Hal ini memaksimalkan penggunaan sumber daya secara efisien dan dapat mengurangi kemungkinan infeksi dan meningkatkan kenyamanan pasien. ${ }^{4}$

Anestesi dapat dilakukan dengan kombinasi droperidol dan opioid yang larut dalam lemak yang disebut sebagai neurolep analgesia untuk mendapatkan keadaan indifference, imobilisasi, dan analgesia. Komplikasi yang sering terjadi dengan teknik tersebut adalah agitasi, ngantuk, nyeri, dan kejang. Lebih jauh neurolep analgesia dapat membawa kearah terjadinya depresi nafas dan kadang-kadang $\mathrm{PaCO}_{2}$ dapat mencapai 45$60 \mathrm{mmHg} .{ }^{1,2,5}$

Beberapa penelitian menggunakan propofol untuk AC. Penggunaan propofol mengurangi kejadian kejang dan agitasi perioperatif, tapi sering terjadi depresi nafas. ${ }^{6}$ Lebih baru lagi, kombinasi propofol dan remifentanil telah sukses untuk anestesi pemetaan otak. ${ }^{7}$ Kedua penelitian tersebut menunjukkan adanya episode depresi nafas, obstruksi jalan nafas, dan desaturasi. Selain itu, propofol dosis besar dapat meningkatan exitotoksisitas glutamat, tidak mempunyai efek proteksi otak, dan dapat menyebabkan kerusakan neuron bertambah banyak. ${ }^{8}$

Makalah ini melaporkan penggunaan dexmedetomidin infus untuk awake language mapping dan reseksi tumor serebral. Dexmedetomidin adalah suatu a-2 agonist dengan efek sedasi, analgesi, anesthetic sparring effect, cepat bangun bila distimuli, tidak mendepresi nafas, mempunyai efek proteksi otak, serta tidak menimbulkan adiksi sehingga pemakaian dexmedetomidin untuk AC dapat dipertimbangkan. ${ }^{1}$ Tidak adanya efek depresi nafas merupakan keuntungan dexmedetomidin yang paling utama dibandingkan dengan teknik anestesi lain untuk AC. Dosis yang dianjurkan adalah dosis bolus $1 \mathrm{ug} / \mathrm{kgBB}$ yang diberikan dalam waktu 10-15 menit, lalu dilanjutkan dengan dosis rumatan $0,2-0,7 \mathrm{ug} / \mathrm{kgBB} / \mathrm{jam}$. Dexmedetomidin menunjukkan adanya penurunan tekanan darah dan denyut jantung sesuai dengan besarnya dosis akan tetapi perubahannya minimal. ${ }^{1,2,9-11}$

\section{Sejarah Awake Craniotomy}

Operasi tulang tengkorak merupakan operasi tertua dari seluruh usaha pembedahan yang 

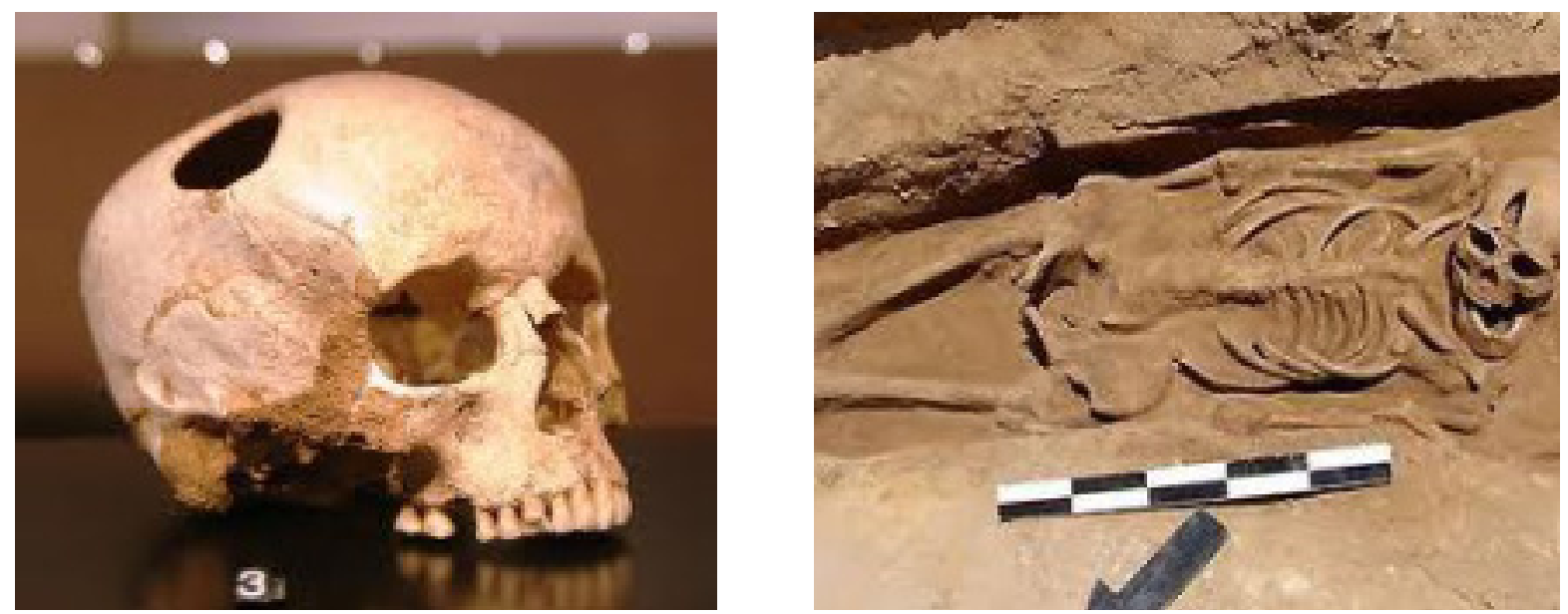

Gambar1. Penemuan arkeologis. Trepanasi pada zaman prasejarah

ada dan telah dilakukan pada zaman prasejarah (gambar1). Sisa-sisa peninggalan tengkorak jauh dibelakang periode akhir paleolithikum menunjukkan bahwa manusia telah menemukan beberapa metode dalam membuka tulang tengkorak. Hanya di Australia (tetapi tidak di New Zealand), Tanjung Malaya, Jepang, Cina, dan diantara Negara Afrika tidak satupun bukti didokumentasikan tentang bedah tengkorak. Banyak orang yang bertahan cukup lama tidak hanya pada proses penyembuhannya tapi juga untuk operasi kembali. Nenek moyang kita ada dan memiliki pengetahuan mengenai anatomi, jahitan bedah dan muara vena besar yang jarang dilanggar. Pembukaan tidak hanya di area mastoid dan dura biasanya dibiarkan tetap intak. ${ }^{12}$

Bagaimana pasien dimanipulasi saat tindakan tidak diketahui, tidak ada bukti bahwa anestesi sudah ada pada zaman neolitikum di Eropa. Daun koka ada di Peru kemampuannya untuk menghilangkan nyeri telah diketahui sejak awal, dan mungkin tindakan anestesi zaman nenek moyang dengan mengunyah daun koka dan kemudian diberikan pada luka. Jadi diperkirakan pasien tetap sadar pada saat dilakukan trepanasi. Tehnik tersebut telah digunakan dan digambarkan selama beberapa abad di Amerika Selatan. ${ }^{12}$

Catatan arkeologis menunjukkan bahwa pada saat prasejarah, ribuan tahun yang lalu, pasien kejang diobat dengan trepanasi tulang tengkorak. Prosedur ini telah sukses dipraktekan jauh sebelum adanya anestesi umum. Masa modern dari AC dimulai akhir tahun 1920-an ketika Wilder Penfield berusaha mengobati pasien dengan epilepsi yang membandel. Penfield dan Andre Pasquet mempublikasikan naskah tentang aspek bedah dan anestesi setelah pemberian anestesi lokal dan sedasi-analgesi intermiten. Teknik ini berhasil dan diterima sebagai teknik pembedahan di seluruh dunia untuk terapi epilepsi. Sebagai tambahan, teknik AC juga dipakai untuk operasi tumor otak. ${ }^{13}$

TeknikAC rudimenterpertamakali didokumentasi pada awal abad ke-17 untuk operasi tumor otak pada pasien dengan epilepsi, dan baru-baru ini dilakukan untuk reseksi tumor yang terdapat di eloquent cortex misalnya lobus frontalis dan lobus temporalis. Testing neurologik intraoperatif memungkinkan dilakukannya reseksi tumor secara maksimal seraya mempertahankan fungsi neurologis. ${ }^{12,13}$

Pada jaman prasejarah, AC telah digunakan untuk trepanasi guna mengobati kejang dan memulihkan berbagai kondisi atau mengeluarkan udara jahat. Pada zaman modern, teknik ini pertama kali digunakan untuk mengambil fokal epileptik yang secara simultan dilakukan pemetaan otak. Perkembangan selanjutnya menyebabkan teknik ini digunakan untuk reseksi tumor otak di daerah eloquent cortex. Baru-baru ini AC telah dipakai untuk semua tumor supratentorial, tanpa memandang apakah mengenai eloquent cortex atau tidak. Awake craniotomy telah digunakan di 
Amerika Utara sejak tahun 1980-an, kemudian ke Eropa dan menyebar ke Asia. Di Indonesia AC dimulai tahun 2003. ${ }^{12,13}$

\section{Keuntungan Awake Craniotomy}

Awake craniotomy mempunyai dua keuntungan dibandingkan dengan pembedahan biasa dengan anestesi umum yaitu 1) memberikan kesempatan pemetaan cortex dan subcortex untuk mengurangi morbiditas neurologis dan memaksimalkan luasnya operasi 2) untuk menghindari morbiditas akibat anestesi umum dan lebih cepat keluar dari rumahsakit. Tidak ada penelitian randomized controll yang telah dilakukan untuk mendukung pernyataan tadi, akan tetapi, pendukung teknik ini yakin akan menguntungkan untuk pasien. ${ }^{2,14}$

Mengenai morbiditas akibat anestesi umum, ternyata lambatnya pemulihan fungsi kognitif telah jauh berkurang dengan adanya obat anestesi dengan mula kerja dan lama kerja yang singkat, akan tetapi tetap masih ada hang over farmakologis yang dihubungkan dengan anestesi umum. Selain itu, ada kemungkinan rasa tidak nyaman dan morbiditas akibat monitoring invasif, laringospasme akibat intubasi endotrakheal, sepsis dari pemasangan kanula arteri atau CVP, dan sepsis urinari akibat pemasangan kateter. 2,14 Hasil akhir dari komplikasi AC yang rendah dan kurangnya efek samping anestesi dapat ditunjukkan dengan lebih cepatnya pemulihan dari pembedahan dengan kurangnya morbiditas neurologis dan lebih singkatnya tinggal di rumahsakit. Kenyamanan dan keamanan teknik ini memungkinkan dilakukannya kraniotomi sebagai bedah rawat jalan. ${ }^{2,14}$

Tidak seluruh kraniotomi dapat dilakukan dengan teknik AC, misalnya operasi fossa posterior dengan posisi telengkup, operasi yang sangat lama, pasien yang confus, dementia, agitasi, tidak bisa bicara atau mendengar perintah, atau menolak dilakukan AC. Bukan merupakan calon $\mathrm{AC}$ adalah pasien yang tidak kooperatif misalnya adanya disphasia berat dan confusion atau pasien yang memerlukan posisi prone atau tumor yang menginvasi dura secara nyata, karena adanya nyeri saat dilakukan reseksi dura. Pasien pada umumnya datang beberapa minggu sebelum operasi dan tentu pertama kali adalah bertemu dengan dokter bedahnya, bukan dengan dokter anestesi, dengan demikian dokter bedah saraf akan melakukan terapi psikologis, menerangkan tentang bagaimana jalannya operasi dengan teknik "bangun". Pasien diajari bahwa akan sedikit sakit saat menyuntikan obat anestesi lokal, harus menurut bila diminta menghitung, dan menggerakkan tangan atau kaki.,14

\section{Sasaran Anestesi}

Sasaran pengelolaan anestesi selama AC untuk operasi tumor otak adalah supaya pasien nyaman, tidak bergerak diatas meja operasi selama pembedahan berlangsung dan bangun serta sadar ketika dilakukan pemetaan korteks. Sasaran tersebut dapat dicapai dengan 1) persiapan pasien yang adekuat 2) lingkungan yang nyaman 3) pemberian sedatif dan analgesi yang tepat 3) selalu berkomunikasi dengan pasien dan meng"support" pasien 4) terapi yang cepat bila terjadi komplikasi. ${ }^{2}$

Sasaran anestesi adalah transisi yang lancar antara anestesi dan sadar. Pada saat tidur ditargetkan kedalaman anestesi yang adekuat ketika membuka dan menutup tulang. Pada saat bangun pasien harus dalam keadaan bangun penuh untuk dilakukan pemetaan korteks. Ventilasi harus adekuat dan jalan nafas aman, pasien tidak bergerak saat operasi tapi tetap merasa nyaman dan kooperatif, dan mampu dilakukan pemantauan elektrofisiologik. Operasi dapat melakukan maksimal reseksi tumor tanpa mengganggu fungsi neurologis. Pemetaan intraoperatif menolong membedakan antara eloquent cortex dan jaringan tumor, yang memfasilitasi akses tumor dari rute transkortikal yang paling aman, melakukan reseksi tumor secara agresif sambil mempertahankan jaringan yang mempunyai fungsi.

\section{Persiapan Pasien}

Keberhasilan AC bergantung pada pemilihan dan persiapan pasien. Seleksi pasien yang pertama dilakukan oleh dokter bedah saraf dan dimulai dengan persiapan psikologis pasien, kemudian dilanjutkan oleh dokter anestesi saat bertemu pasien ketika konsultasi prabedah. Peranan 
dokter anestesi juga untuk menilai apakah pasien dapat menjalankan prosedur awake, mendapatkan hubungan dokter-pasien dan memberikan ketenteraman bagi pasien. Pasien harus diberi informasi apa yang dilakukan selama prosedur termasuk latihan apa yang harus dilakukan ketika distimulasi.

Pemeriksaan pasien yang rutin adalah evaluasi sistem kardiovaskuler dan respirasi, pemeriksaan laboratorium, EKG, dan thoraks foto. Setiap defisit neurologis harus dicatat. Obat yang diberikan pada pasien sebelum pembedahan misalnya antihipertensi, kortikosteroid, antikonvulsi, harus tetap diteruskan. Premedikasi mungkin tidak diperlukan, terlebih-lebih bila pasien datang di hari operasi. Kalau pasien rawat inap dapat diberikan lorazepam. ${ }^{2}$

Seleksi pasien prabedah adalah untuk menemukan apakah ada kontraindikasi absolut (pasien tidak kooperatif), kontra indikasi relatif (adanya obstructive sleep apnoe/OSA, morbid obes, tumor pembuluh darah yang besar, tumor yang mengenai duramater). Untuk persiapan pasien, kunci utamanya adalah pasien harus percaya diri dan setuju untuk kooperatif selama operasi, dan mengembangkan hubungan yang baik dengan pasien dan keluarganya merupakan hal yang penting. Komunikasikan apa yang kita harapkan dari pasien dan apa yang diinginkan pasien dari kita dan prinsipnya komitmen, aman, dan nyaman. Periksa apakah ada kemungkinan kesulitan ventilasi dan intubasi. Tanyakan berat dan jenis epilepsi serta obat antiepilepsi yang dimakan. Tanyakan ada riwayat mual muntah. Cari adanya risiko perdarahan dengan melihat tipe dan lokasi tumor, dan terapi antikoagulan. Toleransi pasien terhadap nyeri dan tingkat kecemasan pasien serta adakah defisit neurologis. ${ }^{2}$ Memberikan keterangan yang tepat pada pasien merupakan ansiolisis yang sangat baik. Obat yang dapat diberikan antara lain: benzodiazepin, opioid, antiemetik, antibiotik, antikonvulsan, steroid, klonidin, atropin. Midazolam merupakan obat premedikasi yang paling sering diberikan. Beberapa penulis memberikan NSAID diclofenac atau asetaminofen. ${ }^{2}$

\section{Persiapan Kamar Bedah}

Kamar bedah merupakan ruangan yang tidak familier untuk pasien. Sebelum pasien dibawa masuk ke kamar bedah, para perawat dan dokter bedah saraf harus sudah siap sehingga semua anggota tim termasuk dokter anestesi, dapat mencurahkan perhatian pada pasien. Lingkungan harus tenang dan menyenangkan dengan suhu ruangan yang tepat. Meja operasi harus selunak mungkin, kalau perlu diberi tambahan matras, ganjal bagian yang dirasakan tidak enak, beri bantal, pada prinsipnya tanyakan ke pasien apakah posisinya sudah nyaman atau belum, jadi buat posisi senyaman mungkin. Untuk dokter anestesi persiapannya termasuk persiapan obat, alat monitor, mesin anestesi, sebab harus sudah siap bila terjadi komplikasi dan bila diperlukan anestesi umum. Persiapan lengkap untuk managemen jalan nafas, jalur vena, alat pantau. Untuk kenyamanan pasien disiapkan suhu kamar oprasi yang hangat, selimut hangat, bantal, ruangan tidak ribut. Tulis di pintu kamar oprasi "pasien bangun" atau ada AC. Posisi pasien harus memungkinkan spesialis anestesiologi dapat mengakses muka dan jalan nafas pasien. ${ }^{2}$

\section{Posisi Pasien}

Posisi pasien akan bergantung dimana lokasi tumor. Posisi lateral lebih menguntungkan bila terjadi obstruksi jalan nafas, mualmuntah, dan kejang. Posisi supine juga baik, untuk memudahkan melihat muka pasien dan membebaskan jalan nafas. Penting bahwa pasien harus bisa melihat dokter anestesi dan dokter anestesi harus bisa melihat pasien. Penempatan posisi kepala tergantung dari dokter bedah sarafnya. Posisi pasien harus memudahkan pasien menggerakan tangan atau kakinya. Paling baik diletakkan mikrophone didekat mulut pasien supaya pasien tidak berteriak bila diminta menghitung oleh dokter bedah saraf. ${ }^{2}$

\section{Pengelolaan Anestesi}

\section{1) Monitor}

Standar monitor termasuk EKG, tekanan darah non invasif, pulse oksimetri. Tekanan darah invasif tidak perlu. Monitor central venous pressure (CVP) tidak perlu, dengan pengecualian bila ditakutkan adanya emboli udara maka dipasang kateter vena sentral, kateter urine juga tidak diperlukan bila cairan intravena yang 


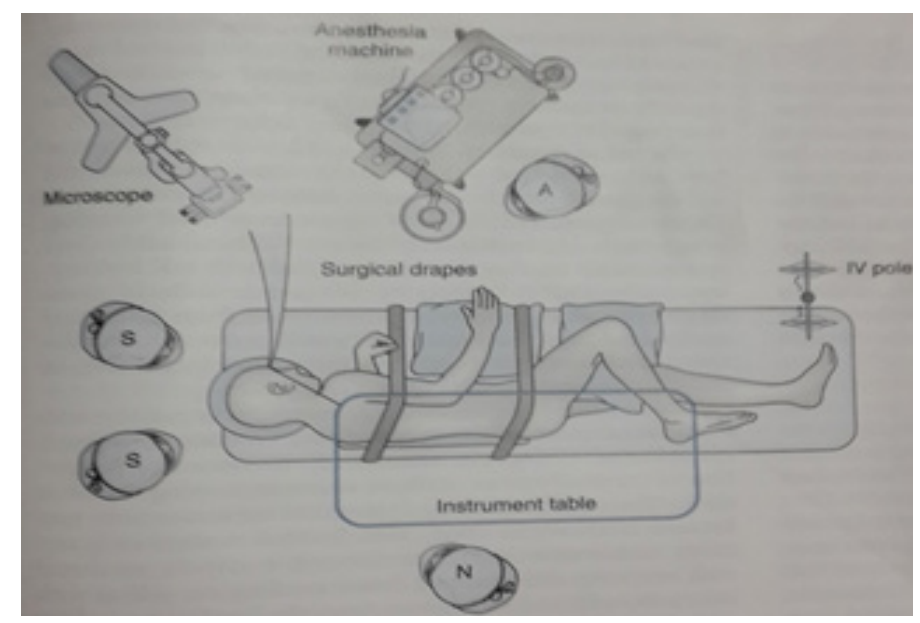

\begin{tabular}{|l|}
\hline Keterangan: \\
A: Anesthesiologist \\
S: Surgeon \\
$\mathrm{N}:$ Nurse \\
\hline
\end{tabular}

Dikutip dari: Cottrell \& Young 2012

diberikan minimal. Oksigen diberikan melalui face mask atau kanul binasal, dan lebih disukai pemakaian kanul binasal karena lebih nyaman untuk pasien dan dapat bebas berbicara. Bila dilakukan test bicara, lebih mudah untuk dokter anestesi untuk melihat muka pasien untuk melihat setiap gejala kejang. Dilakukan pemantauan endtidal $\mathrm{CO}_{2}$ dan oksigen diberikan melalui nasal prong. Tujuan pemasangan capnograph adalah untuk mendeteksi respirasi bukan betul-betul untuk melihat end-tidal $\mathrm{CO}_{2}{ }^{2}$

\section{2) Farmakologi}

Propofol

Propofol telah digunakan secara luas dalam neuroanestesi juga dalam AC untuk periode tidurnya. Propofol mudah dititrasi untuk mendapatkan efek sedatif, pemulihan cepat, menurunkan metabolisme otak (cerebral metabolic rate for oxygen $/ \mathrm{CMRO}_{2}$ ), menurunkan tekanan intrakranial (intracranial pressurel ICP), mempunyai gambaran anti convulsan dan antiemetik.

Walaupun efek propofol terhadap tekanan perfusi otak (cerebral perfusion pressure/CPP) disebabkan oleh efek yang menurunkan tekanan darah, telah ditunjukkan bahwa efek hemodinamik yang tidak menyenangkan tersebut dapat dicegah dengan menghindari efek konsentrasi puncak. Efek propofol terhadap metabolime otak dan aliran drah otak (cerebral blood flow/ $\mathrm{CBF}$ ) sama seperti golongan barbiturat. Pada penelitian manusia, juga diperlihatkan bahwa propofol menurunkan $\mathrm{CBF}$ dan metabolisme otak. Pada pasien dengan cedera otak, anestesia dengan propofol akan menurunkan CPP, ICP dan CBF. Reaktivitas perfusi serebral terhadap $\mathrm{CO}_{2}$ tetap ada. Profopol menurunkan CBF (sebanyak 30\%), $\mathrm{CMRO}_{2}(30 \%)$, dan ICP, tetapi CPP juga menurun disebabkan oleh propofol yang mempunyai efek menurunkan tekanan darah yang hebat. Penelitian lain menyatakan bahwa propofol bisa menurunkan atau tidak mengakibatkan perubahan pada ICP. Dengan infus kontinyu, CPP dipertahankan adekuat sehingga total intravenous anesthesia (TIVA) dengan propofol cukup menyenangkan. Seperti halnya hipnotik sedatif yang lain, depresi susunan saraf pusat terjadi bergantung pada dosis. ${ }^{15}$ Satu penelitian pada hewan coba, menunjukkan bahwa propofol meningkatkan eksotoksisitas glutamat, memicu terjadinya apoptosis, sehingga menambah jumlah kematian sel neuron. ${ }^{8}$

\section{Fentanyl}

Efek narkotik terhadap CBF sulit diperkirakan karena laporan penelitian yang masih kontroversial. Dosis kecil narkotik mempunyai efek kecil pada $\mathrm{CBF}$ dan $\mathrm{CMRO}_{2}$ sedangkan pada dosis besar menurunkan $\mathrm{CBF}$ dan $\mathrm{CMRO}_{2}$. Tidak mempengaruhi autoregulasi dan reaktivitas pembuluh darah otak terhadap $\mathrm{CO}_{2}$. Fentanyl merupakan suatu obat yang mempunyai sifat sangat lipofilik dan dapat menembus sawar darah otak dengan cepat sehingga pemakaian fentanyl melalui intravena akan memberikan 
efek analgetik dengan segera. Hampir sama dengan morfin, fentanyl menghasilkan analgesik kuat untuk pembedahan, menimbulkan depresi pernafasan, bradikardia, mual, dan muntah. Akan tetapi, berbeda dengan morfin, fentanyl mempunyai mula kerja yang cepat, masa kerja singkat, efek mual muntah sedikit, dan relatif tidak berpengaruh pada sistem kardiovaskuler. ${ }^{15}$ Fentanyl merupakan narkotik pilihan pertama untuk neuroanestesia. Penggunaan fentanyl sedikit menurunkan ICP dan mempertahankan CPP lebih baik daripada sufentanil. Fentanyl menurunkan resistensi absorpsi cairan serebrospinal dan menyebabkan penurunan volume darah otak sebesar $10 \%$. Pada dosis tinggi $(>5 \mu \mathrm{g} / \mathrm{kg}$ ) fentanyl menurunkan minimum alveolar concentration (MAC) sebesar 65\%. Dosis yang lebih kecil, lebih cocok untuk bedah saraf dan tidak banyak menurunkan MAC.

\section{Dexmedetomidin}

Dexmedetomidin adalah suatu super-selektif a-2 adrenergik dengan perbandingan $a_{2}$ : a1, 1600:1. Mempunyai efek sedatif dan analgesik, anesthesia sparring effect, menurunkan kebutuhan obat anestesi intravena, anestetika inhalasi, dan narkotik analgetik. Menurunkan tekanan darah dan denyut jantung. Efek sedasi tidak disertai dengan efek depresi nafas, dan pasien mudah dibangunkan dan kooperatif, sehingga dexmedetomidin sangat berguna untuk sedasi analgesi pascabedah dan pasien yang dirawat di ICU. Setelah beberapa penelitian, dexmedetomidin telah disetujui di Amerika pada tahun 1999 dan telah digunakan untuk analgesia dan sedasi di ICU. Akan tetapi, karena berefek stabilitas hemodinamik saat laringoskopi dan intubasi, penurunan kebutuhan obat anestesi, sedasi dan analgesi, menyebabkan obat ini dipakai sebagai adjuvan obat anestesi. . $^{9-13,16,17}$ Obat anestesi untuk pasien dengan kelainan serebral, harus diketahui pengaruhnya terhadap aliran darah otak, volume darah otak, autoregulasi, respons reaktivitas pembuluh darah terhadap $\mathrm{CO}_{2}$, tekanan intrakranial, metabolisme otak, produksi dan absorpsi cairan serebrospinalis, dengan demikian pemberian sedatif untuk AC juga harus diketahui pengaruhnya terhadap halhal tersebut diatas. Oleh karena itu, kualifikasi obat neuroanestesi harus mudah dikendalikan (mula kerja cepat, pemulihan cepat), stabil homeostasis intrakranial, tidak mempengaruhi monitoring neurofisologi, neuroproteksi, dan antinosisepsi. ${ }^{9-13,16,17}$

Secara umum, tujuan pengelolaan anestesi adalah untuk induksi yang lancar, slack brain, mempunyai efek proteksi otak, pemulihan yang cepat dan lancar, serta hemodinamik yang stabil sebab hipotensi akan membawa kearah terjadinya iskemi otak, sedangkan hipertensi dapat menimbulkan terjadinya hiperemia, vasogenik edema, bahkan perdarahan otak. Anesthesia sparring effect dari dexmedetomidin terlihat dengan adanya penurunan dosis propofol, menurunkan MAC isofluran $50-90 \%$. Menurunkan dosis tiopental, MAC isofluran sampai 47\%, MAC sevofluran 17\%. ${ }^{2,9-13,16,17}$

Aktivasi reseptor a-2 dapat menimbulkan sedasi dan ansiolisis, analgesia, penurunan katekholamin plasma, mempunyai efek hipotensi dan bradikardi, diuresis karena menginhibisi pelepasan $\mathrm{ADH}$, efek dekongestan dan antisialogogus. ${ }^{9-13,16-17}$

Efek dexmedetomidin pada aliran darah otak pada binatang percobaan menunjukkan adanya penurunan aliran darah otak sampai $45 \%$, tidak mempunyai pengaruh pada metabolisme otak, konstriksi pial arteri dan vena, mengurangi efek vasodilatasi akibat hipoksia-hiperkapni. Dexmedetomidin menyebabkan penurunan aliran darah otak pada anjing yang sedang dianestesi dengan isofluran. Intravena dexmedetomidin menghambat dilatasi serebrovascular akibat isofluran and sevofluran. ${ }^{9-13,16-17}$ Pada penelitian manusia dengan transcranial dopler (TCD) menunjukkan adanya penurunan velositas rerata aliran darah otak dengan meningkatnya konsentrasi plasma dexmedetomidin. Index pulsatilitas meningkat pada konsentrasi tinggi dexmedetomidin yang menunjukkan adanya peningkatan resistensi pembuluh darah otak. Penelitian pada binatang menujukkan bahwa tekanan intrakranial tidak berubah walaupun ada peningkatan tekanan darah, akan tetapi, tekanan intrakranial akan menurun bila sebelumnya ada peningkatan tekanan intrakranial. Penelitian pada manusia menunjukkan dexmedetomidin tidak mempengaruhi tekanan cairan serebrospinal 
lumbal pada pasien yang sedang mengalami reseksi tumor hipofise transpenoidal.

Efek neuroproteksi dexmedetomidin disebabkan karena menghambat iskemia yang diakibatkan pelepasan norepinefrin karena dexmedetomidin menurunkan level norepinefrin saat bangun dari anestesi (2 sampai 3 kali lebih rendah daripada plasebo). Dexmedetomidin mencegah kematian sel neuron setelah iskemi fokal dan daerah yang mengalami iskemik turun $40 \%$ dibandingkan dengan plasebo. Dexmedetomidin mempertinggi pembuangan glutamin melalui metabolisme oksidatif pada astrosit. Alpha-2 agonists menurunkan konsumsi oksigen perioperatif. ${ }^{9-13,16-}$ 17

Obat sedatif yang ideal adalah mampu menurunkan $\mathrm{CMRO}_{2}$, menurunkan tekanan intrakranial tanpa menurunkan tekanan perfusi otak, mempertahankan autoregulasi serebral dan reaktivitas pembuluh darah terhadap $\mathrm{CO}_{2}$, mula kerja cepat dan lancar, mudah mengendalikan kedalaman dan lamanya sedasi, pada dosis therapeuticwindowdapatdilakukan evaluasistatus neurologis dan komplikasi. Dexmedetomidin mempunyai sifat: sedasi reversibel tanpa depresi nafas, analgesia, anesthetic sparing effect, kardiovascular stabil, mempunyai efek minimal pada tekanan intrakranial, mempunyai efek neuroproteksi, pasien cepat bangun. Secara teori dexmedetomidin menguntungkan untuk sedasi selama dan pascabedah pada pasien dengan kelainan intraserebral. ${ }^{9-13,16-17}$ Efek samping dexmedetomidin adalah hipotensi, hipertensi selintas, bradikardi, mulut kering, efek amnesi sedikit. Melihat efek dexmedetomidin pada dinamika serebral, kiranya dapat dipertimbangkan pemakaian dexmedetomidin untuk anestesi bedah saraf dan operasi lain yang mana pasien mempunyai kelainan serebral. ${ }^{9-13,16,17}$

\section{3) Scalp Anestesi}

Dilakukan infiltrasi lokal anestesi dengan menggunakan bupivakain $0,25 \%$ atau levobupivakain yang ditambah epinefrin $1 / 200.000$. Penambahan epinefrin dimaksudkan untuk menambah lama kerja obat anestesi lokal dan mengurangi perdarahan saat menyayat sclap. Dosis bupivakain-epinefrin total yang aman

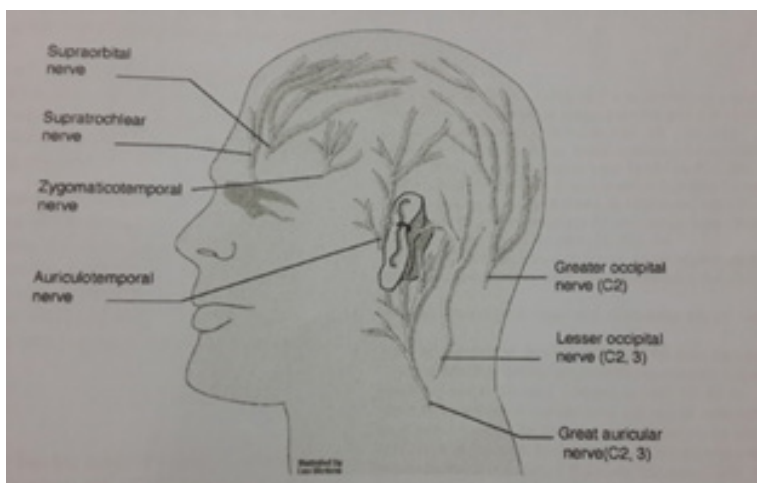

Gambar 2. Salah satu cara scalp blok

adalah $2,5 \mathrm{mg} / \mathrm{kg}$. Umumnya bisa diberikan $40-$ $50 \mathrm{ml}$ bupivakain $0,25 \%+$ epinefrin $1 / 200.000$. Harus diingat mula kerja obat anestesi lokal, dari mulai saat menyuntikkan obat anestesi lokal pada daerah yang akan dipasang head pin (kira-kira 2 $\mathrm{ml}$ setiap tempat) sampai dipasang head pin. ${ }^{2}$

\section{4) Teknik Anestesi}

Managemen anestesi sangat penting untuk keberhasilan AC. Ada 2 teknik anestesi utama yang digunakan untuk AC. Teknik yang paling sering digunakan adalah monitored conscious sedation, dan cara lain adalah teknik asleepawake-asleep (AAA). Analgesia dapat diberikan secara intravena, anestesi local, atau scalp block.

a) Monitored conscious sedation

Awake craniotomy yang tradisional adalah mempertahankan pasien dalam conscious sedation atau neurolept analgesia di seluruh masa pembedahan. Sedasi dihentikan sebelum akan dimulainya testing stimulasi. Umumnya tidak ada manipulasi jalan nafas selama prosedur. ${ }^{2}$

b) Asleep-awake-asleep (AAA)

Dengan menggunakan anestesi umum dengan laryngeal mask airway (LMA) atau diintubasi dengan pipa endotrakheal untuk pengelolaan jalan nafas selama kraniotomi. Kemudian pasien dibangunkan, LMA atau pipa endotrakhealnya diangkat, dan dilakukan testing. Setelah selesai testing dilakukan anestesi umum dan LMA atau pipa endotrakheal dipasang lagi. ${ }^{2}$

\section{5) Induksi Anestesi}

Induksi anestesi dimulai bila posisi pasien di meja operasi sudah nyaman. Insersi head pin sangat sakit, karena itu dokter bedah saraf harus 
memberikan anestesi lokal di setiap tempat yang akan dipasang head pin. Tindakan menyuntikan obat anestesi lokal tersebut dapat menimbulkan rasa sakit dan kecemasan pasien, maka obat analgesi dan sedatif harus diberikan sebelum menyuntikan obat anestesi lokal. Salah satu teknik adalah pasien terlebih dulu diberi dosis bolus dexmedetomidin $1 \mathrm{ug} / \mathrm{kg}$ BB yang diberikan selama 10-15 menit, setelah pasien tersedasi dexmedetomidin dosisnya diturunkan menjadi $0,4 \mathrm{ug} / \mathrm{kg} / \mathrm{jam}$, bila perlu dapat ditambahkan fentanil $1 \mathrm{ug} / \mathrm{kg}$ BB diberikan pelan-pelan, lalu dilakukan penyuntikan anestesi local didaerah yang akan dipasang head-pin. Setelah dipasang head pin, pasien dibangunkan untuk menanyakan apakah posisinya sudah nyaman atau belum. Pada saat infiltrasi scalp, juga dexmedetomidin diteruskan dan pasien ditidurkan dengan propofol $2 \mathrm{mg} / \mathrm{kg}$. Selama insisi scalp dan kraniotomi pasien ditidurkan dan setelah dura dibuka pasien dibangunkan untuk dimulainya pemetaan otak dan reseksi tumornya. ${ }^{1,2}$

\section{6) Komunikasi dengan Pasien}

Selain pemberian sedasi, komunikasi yang terus menerus dan menenteramkan pasien merupakan hal yang penting, antara lain memberitahu bila bakal ada rangsangan yang sakit, atau suara ribut saat membor tulang tengkorak. Juga membasahi bibir pasien, memegang tangannya akan sangat membantu dalam menenteramkan pasien. ${ }^{2}$

\section{7) Komplikasi}

Semua komplikasi yang mungkin terjadi harus dipertimbangkan sebelum dimulainya pembedahan. Diperlukan persiapan untuk pengobatan komplikasi ini. Komplikasi intraoperatif yang sering terjadi adalah obstruksi jalan nafas karena terjadi oversedasi, kejang yang bisa fokal dan singkat atau menyeluruh, gelisah, mual-muntah, komplikasi hemodinamik, toksisitas anestetika local, nyeri, tidak kooperatif dan diperlukannya anestesi umum. Komplikasi lain yang jarang terjadi adalah emboli udara (pada operasi fossa posterior). ${ }^{2}$

a) Komplikasi Jalan Nafas

Bila pasien mengalami penurunan frekuensi nafas, desaturasi, atau obstruksi total jalan nafas, dokter anestesi harus merencanakan secara sistematis untuk mengatasi masalah ini. Bila masalahnya adalah oversedasi, maka pemberian sedasi harus dihentikan dan bila diperlukan bantuan jalan nafas dengan chin-lift atau dengan sungkup dan bantuan nafas. Akan tetapi, bila hilangnya jalan nafas disebabkan karena kejang, atau karena masalah intrakranial, maka diperlukan intubasi. Teknik dan pemilihan insersi pipa endotrakhea bergantung pada keahlian dokter anestesi tersebut. Bila pasien bangun dapat diinduksi dengan propofol, opioid, tanpa atau dengan pelumpuh otot. $^{2}$

b) Kejang

Kebanyakan kejang terjadi saat stimulasi listrik ketika melakukan cortical mapping, tapi bila pasien mempunyai riwayat kejang sebelum pembedahan, maka kejang dapat terjadi setiap saat. Pengobatannya adalah segera membuat diagnosa dan terapi secepat mungkin. Pasien memerlukan proteksi dari cedera terutama akibat pergerakan saat kejang yang hebat. Bila kejang berlangsung lama, jalan nafas harus dibebaskan. Kejang dapat dihentikan dengan dosis kecil pentotal $(50 \mathrm{mg})$, propofol (20mg), atau midazolam 1-2 mg, dosis ulangan mungkin diperlukan bila kejang tetap berlangsung. Antikonvulsan yang bekerja lama seperti fenitoin mungkin diperlukan. Ada bukti yang nyata bahwa irigasi korteks dengan larutan dingin dapat menolong. ${ }^{2}$

\section{c) Mual dan Muntah}

Mual-muntah intraoperatif sering terjadi selama operasi epilepsi. Akan tetapi, kejadian selama AC untuk operasi tumor sangat rendah dan komplikasi yang terjadi pascabedah lebih sedikit dibandingkan dengan anestesi umum. Bila terjadi mual-muntah dapat diterapi dengan ondansetron. ${ }^{2}$

\section{d) Pasien tidak kooperatif}

Kadang-kadang beberapa pasien menjadi sangat gelisah, agitasi, atau tidak kooperatif selama prosedurwalaupunnampaknyapenilaian prabedah adekuat dan diperkirakan pasien dapat dilakukan AC. Pada beberapa pasien kejadian tersebut adalah akibat dari pemakaian propofol. Terapinya adalah dengan mendangkalkan level sedasi sehingga kita dapat berkomunikasi dengan pasien, mengubah obat yang diberikan, mendalamkan level sedasi, atau dirubah ke anestesi umum., ${ }^{1,2}$ 
Teknik memberikan anestesi/sedasi. ${ }^{2}$

1. Pasien disiapkan seperti biasa: puasa prabedah, pemeriksaan lab, obat yang biasa dimakan tetap diteruskan, pasien diwawancara /diberitahu tentang teknik anestesi dan apa yang harus dilakukan selama pemetaan otak.

2. Pasang monitor tekanan darah noninvasif, $\mathrm{EKG}, \mathrm{SpO}_{2}$, oksigen binasal. Tidak dipasang kateter urine, CVP, atau tekanan darah invasif.

3. Meja operasi disiapkan senyaman mungkin, pasien ditanya apakah posisinya sudah enak atau belum. Temperatur ruangan diatur.

4. Larutkan $2 \mathrm{ml}$ dexmedetomidin $(2 \mathrm{ml}$ precedex mengandung 200 ug dexmedetomidin) dengan $48 \mathrm{ml} \mathrm{NaCl} 0,9 \%$ dalam spuit 50 $\mathrm{ml}$, sehingga per cc mengandung 4 ug dexmedetomidin.

5. Dosis bolus $1 \mathrm{ug} / \mathrm{kg}$ yang diberikan dalam waktu 10-15 menit, kemudian dosis diturunkan menjadi $0,4 \mathrm{ug} / \mathrm{kg} \mathrm{BB} / \mathrm{jam}(0,2-$ $0,7 \mathrm{ug} / \mathrm{kg} / \mathrm{jam})$. Dexmedetomidin diteruskan sampai operasi selesai.

6. Ditempat yang akan dipasang head pin diberi anestesi lokal dengan $2 \mathrm{ml}$ bupivakain $0,25 \%$ + adrenalin $1 / 200.000$.

7. Saat dipasang head pin pasien dalam kedaan tidur dengan propofol $2 \mathrm{mg} / \mathrm{kg}$. Bila analgesi dilihat tidak adekuat dapat ditambah fentanyl $1 \mathrm{ug} / \mathrm{kg}$ BB yang diencerkan menjadi $5 \mathrm{ml}$ dan suntikan pelan-pelan.

8. Di daerah yang akan disayat dilakukan blokade saraf scalp dengan bupivakain $0,25 \%+$ adrenalin $1 / 200,000$ sebanyak $40 \mathrm{cc}$.

9. Pasien dibangunkan kembali, dan ditanya apakah posisi kepala sudah enak atau tidak. Operasi bisa dimulai dengan keadaan tidur dengan propofol (Propofol yang dipakai biasanya paling banyak $20 \mathrm{ml}$ ) sampai selesai mengangkat tulang tenggkorak.
10. Setelah duramater dibuka pasien dibangunkan dan bila diperlukan pemetaan otak pasien diminta bicara dengan menghitung 1 sampai 10 atau menggerakkan tangan atau kaki.

\section{Pengelolaan Pascabedah}

Segera setelah selesai operasi pasien dimonitor untuk beberapa jam di post anesthesia care unit (PACU). Bila stabil dan tidak ada perubahan neurologis, pasien dipindahkan ke ruang perawatan bedah saraf untuk diobervasi dan besok paginya pasien dapat dipulangkan. Dexamethasone tetap diteruskan, bila ada kejang obat antiepilepsi harus diberikan, akan tetapi, tidak diberikan sebagai profilaksis. Pasien tidak dimasukkan ke ICU tapi cukup diobservasi di PACU minimal 4 jam pascabedah sebelum dipindahkan ke ruangan. Pasien yang dimasukkan ke ICU pascabedah adalah pasien yang yang prabedah mempunyai penyakit sistemis yang berat atau kondisi neurologis pascabedah memerlukan pemantauan yang ketat. ${ }^{2}$

\section{Simpulan}

Awake craniotomy dapat dilakukan untuk reseksi tumor hampir semua tumor otak. Dengan teknik AC, lama dan biaya perawatan menurun, dan dapat dilakukan sebagai bedah rawat jalan. Dexmedetomidin yang berefek sedasi, ansiolitik, analgesi, tidak mendepresi nafas, pasien bangun bila distimulasi, mempunyai efek proteksi otak, menurunkan aliran darah otak menyebabkan $\mathrm{AC}$ dapat dilakukan dengan memuaskan dengan dexmedetomidin.

\section{Daftar Pustaka}

1. Bekker AY, Kaufman B, Samir H, Doyle W. The use of dexmedetomidine infusion for awake craniotomy. Anesth Analg 2001;92:1251-3.

2. Bisri T. Pemakaian dexmedetomidine infus untuk awake craniotomy. Anestesia \& Critical Care 2004;22(2):182-89

3. Manninen P, Contreras J. Anesthetic considerationforcraniotomyinawakepatients. 
Int Anesthesiol Clinic 1986;24:157-74.

4. Blanshard HJ, Chung F, Manninen $\mathrm{PH}$, Taylor MD, Bernstein M. Awake craniotomy for removal of intracranial tumor: considerations for early discharge. Anesth Analg 2001;92:89-94.

5. Gignac E, Manninen PH, Gelb AW. Comparison of fentanyl, sufentanil and alfentanil during awake craniotomy for epilepsy. Can J Anaesth 1993;40;421-4.

6. Herrick IA, Craen RA, Gelb AW. Propofol sedation during awake craniotomy for seizure: patient controlled administration versus neurolept analgesia. Anesth Analg 1997;84:285-91.

7. Johnson KB, Egan TD. Remifentanil and propofol combination for awake craniotomy: case report with pharmacokinetic simulations. J Neurosurg Anesthesiol 1998;10:25-9.

8. Cotrell JE. Brain protection in neurosurgery: dos and don'ts. ASA Annual Meeting Refresher Course Lecture, October 2002.

9. Bhana N, Goa KL, Mc Clellan KJ. Dexmedetomidine. Drugs. Adis International 2000;59(2):263-268.

10. Bloor BC, Ward DS, Belleville JP, Maze M. Effect of intravenous dexmedetomidine in humans, hemodynamic changes. Anesthesiology 1992;77:1134-42.

11. Villela NR, Nascimento P. Dexmedetomidine in anesthesiology. Rev Bras Anestesiol 2003;53(1):97-113.

12. Frost EAM. History of neuroanesthesia. Dalam: Albin MS, ed. Textbook of Neuroanesthesia with Neurosurgical and Neuroscience Perspectives. New York: McGraw-Hill; 1997, 1-20
13. Wan Hassan MN. History of awake craniotomy in hospital Universiti Sains Malaysia. Malays J Med Sci. 2013 Oct; 20(5): 67-69.

14. Taylor MD, Bernstein M. Awake craniotomy with brain mapping as the routine surgical approach to treating patients with supratentorial intraaxial tumors: a prospective trial of 200 cases. Jour of Neurosurg 1999; 90(1).

15. Sakabe T, Matsumoto M. Effect of anesthetic agents and other drugs on cerebral blood flow, metabolism, and intracranial pressure. Dalam: Cottrell JE, Young WL, editor. Cottrell and Young's Neuroanesthesia; 2010, 78-94.

16. Ohata $\mathrm{H}$, Iida $\mathrm{H}$, Dohi $\mathrm{S}$, Watanabe $\mathrm{Y}$. Intravenous dexmedetomidine inhibits cerebrovascular dilatation induced by isoflurane and sevoflurane in dogs. Anesth Analg 1999;89:370-7.

17. Zornow MH, Fleisher JE, Scheller MS, Nakakimura K, Drummond JC. Dexmedetomidine, an a2-adrenergic agonist, decreases cerebral blood flow in isoflurane-anesthetized dog. Anesth Analg 1990;70:624-30.

18. Maninen PH, See JJ. Epilepsy, epilepsi surgery, awake craniotomy for tumor surgery, and intraoperative magnetic resonance imaging. Dalam: Newfield P, Cottrell JE, eds. Handbook of Neuroanesthesia, 4th ed. Philadelphia: Lippincott Williams \& Wilkins; 2007, 197-215

19. Schubert A, Lotto M. Awake craniotomy, eplepsy, minimal invasive, and robotic surgery. Dalam: Cottrell JE, Young WL, eds. Cottrell and Young's Neuroanesthesia. 5th ed, Philadelphia: Mosby Elsevier; 2010, 296-316 